\title{
Optimalisasi Tugas Keluarga Dalam Mencegah Dan Mengatasi Perilaku Bullying Dalam Kehidupan Anak
}

\author{
Kili Astarani ${ }^{1}$, Dian Taviyanda ${ }^{2}$ \\ ${ }^{1,2}$ STIKES RS Baptis Kediri, Indonesia \\ astaranikili79@gmail.com
}

\begin{abstract}
ABSTRAK
Bullying merupakan perilaku agresif yang dilakukan oleh seseorang atau kelompok terhadap orangorang atau kelompok lain yang dilakukan secara berulang-ulang dengan cara menyakiti secara fisik maupun mental. Bullying dapat dilakukan oleh seorang anak karena adanya proses meniru atau imitasi dari lingkungan terdekatnya. Bullying dapat terjadi pada anak TK, diantaranya adalah mengejek, menyebarkan rumor, menghasut, mengucilkan, menakut-nakuti (intimidasi), mengancam, menindas, memalak, atau menyerang secara fisik (mendorong, menampar, atau memukul). Diperlukan upaya untuk mencegah dan mengatasi perilaku bullying, yaitu dengan pendidikan kesehatan tentang anti-bullying pada pada orangtua dan anak serta perlunya menggiatkan pengawasan dan pemberian sanksi secara tepat kepada pelaku di TK Tunas Bangsa Kediri. Jumlah orang tua atau keluarga yang mengikuti Pendidikan Kesehatan Keluarga dan Anak Prasekolah dalam upaya mengoptimalkan Tugas Keluarga dalam mencegah dan mengatasi perilaku bullying dalam kehidupan anak di TK Tunas Bangsa adalah 17 orang. Dari 17 orang tersebut, 15 orang belum pernah menerima informasi tentang bullying serta upaya mengatasinya. Setelah diberikan pendidikan kesehatan, dari 17 orang, 13 orang memiliki pengetahuan yang baik, 4 orang memiliki pengetahuan yang cukup, dan tidak ada yang memiliki pengetahuan yang kurang.
\end{abstract}

Kata Kunci: Bullying, Pendidikan Kesehatan, Pengetahuan

Received: October, 25, 2019

Revised: December 14, 2019

Accepted: February 11, 2020

\section{(i) (2)}

This is an open-acces article distributed under the terms of the Creative Commons Attribution-ShareAlike 4.0 International License.

\section{PENDAHULUAN}

Bullying adalah perlakuan agresif dan negatif seseorang atau sekelompok orang secara berulang kali yang menyalahgunakan ketidakseimbangan kekuatan dengan tujuan menyakiti korbannya secara mental atau fisik. Wiyani, 2012. Berdasarkan penelitian dari beberapa ahli, bullying yang banyak dilakukan disekolah umumnya mempunyai tiga karakteristik yang terintegrasi sebagai berikut: 1) adanya perilaku agresi yang menyenangkan pelaku untuk menyakiti korbannya, 2) tindakan itu dilakukan secara tidak seimbang sehingga menimbulkan perasaan tertekan pada korban, 3) perilaku itu dilakukan secara berulang atau terus menerus. Bullying dapat dilakukan oleh seorang anak karena adanya proses meniru atau imitasi dari lingkungan terdekatnya. Pendidikan anak usia dini menjadi pendidikan yang penting bagi seorang anak. Hal ini berkaitan dengan masa pertumbuhan dan perkembangan otak anak yang sudah mencapai $80 \%$ pada usia 6 tahun. Pada usia tersebut segala sesuatu yang diterima anak akan dapat memberikan bekas yang 
kuat dan tahan lama. Kesalahan dalam mendidik anak akan memberikan efek negatif jangka panjang dan sulit diperbaiki.

Komisioner KPAI, 2014 mengakui bahwa hingga kini kekerasan di dunia pendidikan kian memprihatinkan. Berdasarkan data Ikhtisar Eksekutif Startegi Nasional Penghapusan Kekerasan Terhadap Anak 2016-2020 yang dirilis oleh Kementerian Pemberdayaan Perempuan dan Perlindungan Anak (Kemen-PPPA), menunjukan sebanyak 7 dari 10 siswa pernah mengalami kekerasan di sekolah. Sebanyak 45\% siswa laki-laki dan $22 \%$ siswa perempuan menyebutkan, guru atau petugas sebagai pelaku kekerasan di sekolah. Sedangkan 40\% siswa usia 13-15 tahun dilaporkan pernah mengalami kekerasan fisik oleh teman sebaya, dan $75 \%$ siswa mengaku pernah melakukan kekerasan di sekolah. Lebih parah, sebanyak 50\% anak dilaporkan mengalami perundungan atau bullying di sekolah. Berdasarkan hasil wawancara yang dilakukan peneliti kepada salah satu orang tua anak di TK Tunas Bangsa, didapatkan bahawa masih ada perilaku anak menakuti-nakuti, menyerang secara fisik (mendorong, memukul) teman ketika anak tidak dapat menyelesaikan masalah saat mereka bermain bersama

Pada anak usia dini, mayoritas kehidupan anak adalah bermain, baik bermain sendiri maupun dengan teman-temannya. Pada saat kegiatan bermain bersama, maka muncul suatu interaksi sosial, dengan demikian potensi untuk terjadi tindakan kekerasan, pemaksaan kehendak dan perbedaan pendapat dapat terjadi. Ketika terjadi permasalahan dalam interaksi antar anak, ada anak yang dapat menyelesaikannya dengan baik, namun ada pula yang tidak. Anak yang tidak dapat menyelesaikan masalah dengan baik pun terbagi dua, yaitu mereka yang menggunakan kekerasan dan mereka yang pasrah.

Beberapa penelitian telah membuktikan bahwa bullying dapat terjadi pada anak TK. Contoh perilaku bullying antara lain mengejek, menyebarkan rumor, menghasut, mengucilkan, menakut-nakuti (intimidasi), mengancam, menindas, memalak, atau menyerang secara fisik (mendorong, menampar, atau memukul) (Tisna, 2010). Banyak pihak menganggap bahwa pada usia dini sikap dan perilaku anak selalu dapat dikontrol sehingga berpendapat bahwa perilaku bullying tersebut merupakan hal sepele atau bahkan "normal" dalam kehidupan sehari-hari. Namun demikian, perilaku bullying merupakan sesuatu gangguan yang dialami oleh anak yang berupa "learned behaviors". Bullying merupakan perilaku tidak "normal", tidak sehat dan secara sosial tidak bisa diterima. Karena manusia tidak terlahir sebagai penggertak dan pengganggu yang lemah. Dengan demikian jika perilaku mengganggu dilakukan secara berulang kali pada akhirnya dapat menimbulkan dampak serius dan fatal di kemudian hari

Pencegahan munculnya perilaku agresif pun harus dilakukan sejak dini, karena sudah banyak penelitian yang membuktikan bahwa perilaku anak usia dini dapat memprediksi kemampuan penyesuaiannya terhadap lingkungan di masa depan. Anak usia prasekolah yang sudah dapat menunjukkan simpati dengan teman, cenderung akan dapat mempertahankan kemampuannya untuk berempati. Program anti-bullying pada anak di sekolah dapat dilakukan dengan cara menggiatkan pengawasan dan pemberian sanksi secara tepat kepada pelaku, atau melakukan kampanye melalui berbagai cara. Memasukkan materi bullying ke dalam pembelajaran atau melakukan pendidikan kesehatan kepada orang tua dana anak akan berdampak positif bagi pengembangan pribadi anak. Pendidikan kesehatan merupakan upaya untuk mencapai hal tersebut (Kemenkes, 2011). Pendidikan kesehatan yang dilakukan kepada orangtua dan anak merupakan salah satu upaya untuk meningkatkan kesadaran kesehatan dalam rangka pemberdayaan masyarakat. Pendidikan kesehatan tentang bullying pada orangtua dan anak di masyarakat sangat penting. 


\section{Journal of Community Engagement in Health}

http://jceh.org

ISSN: 2620-3758 (print); 2620-3766 (online)

https://doi.org/10.30994/jceh.v3i1.31

Vol.3 No.1. March 2020. Page.39-43

\section{BAHAN DAN METODE}

Pengabdian kepada masyarakat ini dilaksanakan di TK Tunas Bangsa Kediri. Metode yang digunakan dalam upaya mengoptimalkan Tugas Keluarga dalam mencegah dan mengatasi perilaku bullying dalam kehidupan anak dengan metode ceramah dan diskusi serta dilakukan monitoring yang bekerjasama dengan Guru TK Tunas Bangsa Kediri selama 3 bulan. Sasaran pelaksanaan adalah anak dan orang tua anak TK Tunas Bangsa Kediri

\section{HASIL}

Berikut distribusi frekuensi orang tua atau keluarga yang mengikuti Pendidikan Kesehatan Keluarga dan Anak Prasekolah dalam upaya mengoptimalkan Tugas Keluarga dalam mencegah dan mengatasi perilaku bullying dalam kehidupan anak di TK Tunas Bangsa pada tanggal 24 Juli 2019 adalah sebagai berikut:

Tabel 1. Distribusi Frekuensi Jenis kelamin orang tua atau keluarga

\begin{tabular}{ccc}
\hline No & Jenis Kelamin & Jumlah \\
\hline 1 & Laki-laki & 3 \\
\hline 2 & Perempuan & 14 \\
\hline
\end{tabular}

Tabel 2. Distribusi Frekuensi Tingkat Pendidikan orang tua atau keluarga

\begin{tabular}{ccc}
\hline No & Tingkat Pendidikan & Jumlah \\
\hline 1 & SD & 1 \\
\hline 2 & SMP & 5 \\
\hline 3 & SMA & 9 \\
\hline 4 & Sarjana & 2 \\
\hline
\end{tabular}

Tabel 3. Distribusi Frekuensi Penerimaan Informasi sebelum Penjelasan tentang Deteksi Dini untuk Mencegah dan Mengatasi Perilaku Bullying

\begin{tabular}{ccc}
\hline No & Penerimaan Informasi & Jumlah \\
\hline 1 & Menerima & 2 \\
\hline 2 & Tidak Menerima & 15 \\
\hline
\end{tabular}

Tabel 4. Distribusi Frekuensi Pengetahuan orang tua atau keluarga setelah Penjelasan tentang Deteksi Dini untuk Mencegah dan Mengatasi Perilaku Bullying

\begin{tabular}{ccc}
\hline No & Tingkat Pengetahuan & Jumlah \\
\hline 1 & Baik & 13 \\
\hline 2 & Cukup & 4 \\
\hline 3 & Kurang & 0 \\
\hline
\end{tabular}

\section{PEMBAHASAN}

Kegiatan pengabdian kepada masyarakat melibatkan orang tua atau keluarga serta guru TK Tunas Bangsa Kota Kediri dalam Pendidikan Kesehatan Keluarga dan Anak Prasekolah dalam upaya mengoptimalkan Tugas Keluarga dalam mencegah dan mengatasi perilaku bullying dalam kehidupan anak. Kegiatan pengabdian masyarakat diawali bulan Juni 2019, dimana pengabdi melakukan pengamatan dan tanya jawab kepada guru TK terkait perilaku anak TK Tunas Bangsa selama mereka beradaptasi dengan siswa yang lain selama di sekolah. Dilanjutkan dengan kegiatan pendidikan kesehatan dilaksanakan pada 
tanggal 24 Juli 2019, evaluasi terhadap anak disekolah TK Tunas Bangsa terhadap perilaku bullying dilaksanakan pada bulan Agustus dan September 2019 yang dilakukan oleh Pengabdi bekerjasama dengan Guru TK Tunas Bangsa.

Pada tanggal 24 Juli 2019, pengabdi bersama dengan Guru TK Tunas Bangsa melakukan pendidikan kesehatan kepada orang tua dan keluarga tentang Deteksi Dini untuk Mencegah dan Mengatasi Perilaku Bullying. Diawali dengan pengkajian tentang pemahaman orang tua atau keluarga tentang perilaku bullying, didapatkan hasil bahwa 15 orang tua atau keluarga belum pernah menerima pendidikan kesehatan tentang bullying. Hasil wawancara dengan orang tua dan keluarga, ada beberapa anak yang mengadu kepada orang tua tentang perilaku teman sebayanya di sekolah yang selalu mengejek karena gendut, ada beberapa anak yang membuat group sendiri ketika bermain.

Bullying merupakan bagian dari kehidupan sehari-hari sebagian besar siswa di sekolah, korban intimidasi atau bullying memiliki dampak negatif yaitu terkait kesehatan mentalnya (Hidayat, 2011). Perilaku bullying pada anak disebabkan kerena dua faktor yaitu faktor internal (dalam) dan factor eksternal (luar). Faktor internal sendiri dapat terjadi karena harga diri anak, pemahaman moral anak yang rendah sedangkan faktor eksternal dapat terjadi karena sikap orang tua atau keluarga yang terlalu memanjakan anak, sikap terlalu tegas atau kaku yang dimiliki orang tua dan tayangan televisi (Wardhana, 2014)

Penanganan yang tepat untuk mengantisipasi atau mencegah terjadinya perilaku bullying yang dapat berdampak kepada kesehatan mental anak adalah dengan pemberian informasi atau pendidikan kesehatan yang diberikan kepada orang tua dan keluarga tentang deteksi dini perilaku bullying yang didalamnya memuat orang tua dan orang dewasa lainnya hendaknya membangun komunikasi yang akrab dengan anak, dengan demikian dapat cepat mendeteksi dan mengantisipasi segala sesuatu yang bersifat menyimpang, orang tua atau keluarga diharapkan dapat membentuk sikap prososial yang kuat pada anak sedini mungkin, sehingga anak mudah beradaptasi dan berkepribadian kuat, serta diharapkan orang tua atau keluarga dapat memberikan perhatian dan kasih sayang yang cukup pada anak sehingga mereka akan berperilaku baik jika di luar rumah (Wardani, 2017).

Dengan pendidikan kesehatan, diharapkan dapat terjadi perubahan pada diri anak yang ada hubungannya dengan tercapainya tujuan kesehatan perorangan dan masyarakat. Pemberian pendidikan kesehatan diberikan kepada orangtua atau keluarga dengan metode pendidikan massa yaitu ceramah yang didalamnya juga memuat kegiatan sharing tentang perilaku anak terhadap teman sebayanya. Dalam memberikan ceramah pengabdi memberikan alat peraga dalam memberikan pendidkan kesehatan berupa leaflet yang dapat digunakan sebagai sumber informasi bagi orang tua atau keluarga yang mengasuh anak.

Keluarga merupakan kunci utama bagi kesehatan serta perilaku sehat sakit, oleh karena itu keluarga terlibat langsung dalam mengambil keputusan dan terapeutik pada setiap tahap sehat sakit anggota keluarga (Setiadi, 2008). Fungsi utama keluarga salah satu diantaranya adalah fungsi perawatan keluarga, dimana keluarga memberikan perawatan kesehatan yang bersifat preventif dan secara bersama-sama merawat anggota keluarga yang sakit. Kesanggupan keluarga melaksanakan perawatan atau pemeliharaan kesehatan dapat dilihat dari tugas kesehatan keluarga yang dilaksanakan (Mubarak, Chayatin, \& Santoso, 2010). Anak-anak usia dini, yang dalam hal ini duduk di bangku taman kanakkanak memerlukan keluarga dalam melaksanakan tugas kesehatan keluarga. Menurut Setiadi (2008) adapun beberapa hal yang berkaitan dengan tugas kesehatan keluarga meliputi kemampuan untuk mengenal masalah, kemampuan keluarga untuk mengambil keputusan, kemampuan keluarga untuk merawat anggota keluarga yang sakit, kemampuan 
keluarga dalam memodifikasi lingkungan dan kemampuan keluarga dalam memanfaatkan fasilitas pelayanan kesehatan yang ada (Setiadi, 2008).

\section{SIMPULAN}

Setelah diberikan pendidikan kesehatan tentang deteksi dini untuk mencegah dan mengatasi perilaku bullying dalam kehidupan anak sebagai upaya mengoptimalkan tugas keluarga, orang tua dan keluarga memahami tentang pencegahan perilaku bullying dan dampak jika perilaku bullying tersebut terus menerus dibiarkan pada anak yang masih kecil

\section{REFERENSI}

Hidayat, D.R. (2011). Teori dan Aplikasi Psikologi Kepribadian dalam Konseling. Bogor: Ghalia Indonesia

Katyana, Wardhana. (2014). Ebook Buku Panduan Melawan Bullying. Sudah Dong.

KPAI. (2014) UU Perlindungan Anak Pasal 54 No 35 tahun 2014, diakses pada 1 Juli 2019. http://www.kpai.go.id/hukum/undang-undang-republik-indonesia-nomor-35-tahun2014-tentang-perubahan-atas-undang-undang-nomor-23-tahun-2002-tentangperlindungan-anak/\#

Listiyarti. Retno (2017). https://www.kpai.go.id/berita/tanggapan-kpai-soal-videopengeroyokan-murid-sd-di-sumatera-selatan-read-more-at-httpskumparancomkumparannewstanggapan-kpai-soal-video-pengeroyokan-murid-sd-di-sumateraselatanzkkdqr7eellxyfzu, 1 Juli 2019

Wardani, L. K., \& Fajriansyah, F. (2017). Perilaku Bullying Mahasiswa Kesehatan. Journal Of Nursing Practice, 1(1), 17-23. https://doi.org/10.30994/jnp.v1i1.18

Mubarak, W.I., Chayatin, N., \& Santoso, B.A. (2010). Ilmu keperawatan komunitas konsep dan aplikasi. Jakarta: Selemba Medika

Rudi, Tisna. (2010). Ebook Informasi Perilaku Bullying. Indonesian Anti Bullying.

Setiadi, 2008, Konsep dan Proses Keperawatan Keluarga, Graha Ilmu, Yogyakarta

Wiyani, Ardy. (2012). Save Our Children Form School Bullying. Jogjakarta: Arruzz Media 